\title{
Glutamic Acid Application for Enhancement of Growth and Productivity of Okra Plant (Abelmoschus esculentus L. Moench)
}

\author{
EVA SEPTIYANA ${ }^{1 *}$, NINTYA SETIARI ${ }^{1}$, SRI DARMANTI $^{1}$ \\ ${ }^{1}$ Department of Biology, Faculty of Science and Mathematics, Universitas Diponegoro \\ Jl. Prof. Soedarto, Tembalang, Semarang, Central Java, Indonesia. 50275 \\ *Email: eseptiyanaa@gmail.com
}

Received 24 August 2019; Received in revised form 14 November 2019; Accepted 05 December 2019; Available online 30 December 2019

\begin{abstract}
Red okra fruit has high nutritional value and fiber but still has low production. Monosodium glutamate (MSG) consists of sodium and glutamic acid. In plants, sodium can role of replacing potassium, stomata physiology, and chlorophyll biosynthesis. Glutamate serves as the nitrogen donor in primer metabolism and gibberellic acid precursor. The assumption that MSG in plants has a positive impact. This research aimed to examine the effect of MSG and the optimum dosage for enhances of growth and production. This research was conducted with Completely Randomized Designs (CRD) with one factor, is the MSG dosage $(0,3,6$, and $9 \mathrm{~g})$. Quantitative data were analyzed using analysis of variant (ANOVA) dan Duncan's Multiple Range Test (DMRT) at a 95\% confidence level. The result shows that the MSG treatment enhances the growth of the okra based on parameters of plant's height, fresh weight of plant, dry weight of plant and the width of the leaf and enhances the production of the okra based on the flowering time, the number of the flower, the number of the fruit, the percentage of flower becoming fruit, the weight of fruit, width of fruit, and the diameter of the fruit. The optimal dosage of MSG for okra production and growth is $3 \mathrm{~g} / \mathrm{plant}$.
\end{abstract}

Keywords: Abelmoschus esculentus L.; growth; monosodium glutamate; productivity, red Okra

\section{INTRODUCTION}

Red okra fruit (Abelmoschus esculentus L. Moench.) is usually consumed as a vegetable that contains vitamin $\mathrm{A}$, vitamin $\mathrm{C}$ and mineral $\mathrm{Ca}, \mathrm{Mg}$, and Fe. Every $100 \mathrm{~g}$ of young okra contains 33 calories, $7 \mathrm{~g}$ carbohydrates, $3.2 \mathrm{~g}$ fiber and $81 \mathrm{mg}$ calcium (Habiba et al., 2018). However, okra is still uncommon in the market because it has not been widely cultivated by the farmer.

Monosodium glutamate (MSG) is generally known as a flavor enhancer, a sodium salt that is bonded with glutamic acid, with the chemical formula of $\mathrm{C}_{5} \mathrm{H}_{8} \mathrm{O}_{4} \mathrm{NNaH}_{2} \mathrm{O}$. The common composition of MSG consists of $12 \%$ sodium $(\mathrm{Na}), 78 \%$ glutamate, and $10 \%$ water (Löliger, 2000). Sodium is a micronutrient for a plant that can replace the role of potassium (K) and it affects the earth's physical charateristic, especially in structural stability. Potassium $(\mathrm{K}+)$ is an important macronutrient that plays a role in enzyme activation, osmotic and turgor balance, membrane potential regulation, and homeostasis of cytoplasmic $\mathrm{pH}$ (Almeida et al., 2017). In some plants, sodium acts functionally in stomatal physiology and chlorophyll biosynthesis, therefore it increases the photosynthesis activity for plant growth (Wakeel et al., 2011). In plants, glutamate is an amino acid that acts as a nitrosgen donor in primer metabolism (Zhang et al., 2017). Nitrogen can increase photosynthesis activity, cell division, plant growth and plant production (Bassi et al., 2018). According to Gupta \& Chakrabarty (2013), glutamate serves as the precursor of gibberellin hormone (GA) plays a role in the development stage of the plant's generative phase by triggering the transition from the vegetative to the generative growth phase. Gibberellin induces the flowering process and its development. Gibberellin also plays an important role in the elongation of the internode and stimulates division and expansion cells. Glutamate plays a role in amino acid biosynthesis which acts as the plant's defense such as gamma-aminobutyric acid (GABA), arginine, and proline (Seifi et al., 2013). Glutamate is needed for the amino donor, glutathione (GSH) synthesis, 
chlorophyll synthesis precursor and as a plant defense system or response to biotic and abiotic stressors. Glutamate occupies a central position in the metabolism of the amino acids in plants (Kan et al., 2017).

The result in Kan et al. (2017) research shows that glutamate can strengthen the signal pathway that controls metabolism response, growth, and defense in rice seedlings that lack nitrogen. The application of MSG in peanut plant (Arachis hypogaea L.) causes the increasing of plant's height, fasten the flowering time, increasing the number of pods pithy, reduce the number of empty pods, and increasing the weight of 100 peas (Gresinta, 2015). The application of MSG in Brassica chinensis L. increases the plant's height, the leaves' number, and the leaves' length (Novi, 2016). The application of glutamic acid on Kimchi Cabbage leaves can increase the antioxidant enzyme activity. Glutamic acid can reduce physiological damage caused by low temperatures at the early stages of Kimchi cabbage growth (Lee et al., 2017).

This research was aimed to examine the effect MSG application in the growth and production of red okra, also to determine the optimum MSG dosage to enhance the growth and production of red okra.

\section{MATERIALS AND METHODS}

This research was conducted at the Biological Plant Structure and Function Laboratory in Department of Biology, Faculty of Science and Mathematics, Universitas Diponegoro.

Material and equipment. The main material was red okra seed from PT. KnownYou Seed Indonesia, and MSG with the brand of Ajinomoto. The main equipment was ovens and digital balance.

Research design. This research was experimental research used Completely Randomized Design (CRD) which one factor was the MSG dosage, which was 0 (control), 3, 6 , and $9 \mathrm{~g}$, each unit treated with 5 replication.

Preparing the seedling and planting medium, selecting the okra seed, and planting. The planting medium was a mix of fertilizer, husk charcoal, and soil with the ration
$1: 1: 1$. The seedling uses $10 \times 20 \mathrm{~cm}$ plastic while planting uses $40 \times 40 \mathrm{~cm}$ polybag. The base fertilizer that was given before planting consists of fertilizer and $\mathrm{KCl}$ for $10 \mathrm{~g} /$ polybag (Ikrarwati \& Rokhmah, 2016). The seed selection was done by soaking the seed in the water, the seeds that will be used are the sunken ones. The seeds then were sown in the seedling medium for one week (seedling with four leaves). Okra seedling selection based on uniformity of stem height and the amount of the leaves, and then the seedling moved into planting polybag, one seedling for each planting polybag.

\section{Application and maintenance.} Monosodium glutamate application was done when the okra plant was 2 weeks after planting. The MSG dose of the treatment was made by dissolving MSG in water. Treatment was by pouring MSG solution with a treatment dose of $500 \mathrm{ml}$ per plant to the soil around the stem once a week until the end of the vegetative phase. Maintenance was done by watering 500 ml water per polybag every 2 days and removing weeds that grow in polybags.

Harvesting and measuring parameter. Harvesting and measurement of vegetative organ parameters were carried out at the end of the vegetative growth phase which was four weeks after planting. Harvesting of okra fruits begins when the plant was six weeks after planting to nine weeks after planting. Okra fruits were harvested four to six days after the flowers were in full bloom. Harvesting was done in the morning or evening at two-day intervals.

Data Analysis. The quantitative data were analyzed using Analysis of Variance (ANOVA) with the assumption level of $95 \%$. If there were differences, then DMRT (Duncan's Multiple Range Test) tests were used to understand the most effective MSG dosage in okra's growth and production.

\section{RESULT AND DISCUSSION}

Vegetative Growth of Red Okra Plant. The result of Analysis of Variance showed that MSG application had a real impact on okra plant height, fresh weight, dry weight, and the leaf area, however, it did not have a real impact on the leaf number (Table 1). 
Table 1. Okra plant height, fresh weight, dry weight, leaf area, and leaf number 30 days after planting that applied with MSG

\begin{tabular}{lcccc}
\hline \multicolumn{1}{c}{ Variable } & \multicolumn{4}{c}{ MSG Dosage (g) } \\
\cline { 2 - 5 } & 0 & 3 & 6 & 9 \\
\hline Plant Height $(\mathrm{cm})$ & $14.3^{\mathrm{b}}$ & $16.6^{\mathrm{a}}$ & $16.2^{\mathrm{a}}$ & $16.3^{\mathrm{a}}$ \\
\hline Plant Fresh Weight $(\mathrm{g})$ & $2.15^{\mathrm{b}}$ & $3.08^{\mathrm{a}}$ & $2.43^{\mathrm{b}}$ & $2.4^{\mathrm{b}}$ \\
\hline Plant Dry Weight $(\mathrm{g})$ & $0.29^{\mathrm{b}}$ & $0.46^{\mathrm{a}}$ & $0.32^{\mathrm{b}}$ & $0.33^{\mathrm{b}}$ \\
\hline Leaf Area $\left(\mathrm{cm}^{2}\right)$ & $31.50^{\mathrm{c}}$ & $52.08^{\mathrm{a}}$ & $46.50^{\mathrm{ab}}$ & $41.78^{\mathrm{b}}$ \\
\hline Leaf Number & $5.2^{\mathrm{a}}$ & $6.0^{\mathrm{a}}$ & $5.8 \mathrm{a}$ & $6.0^{\mathrm{a}}$ \\
\hline
\end{tabular}

The number that followed by the same alphabet in the same column is not different according to $\alpha 95 \%$ DMRT test.

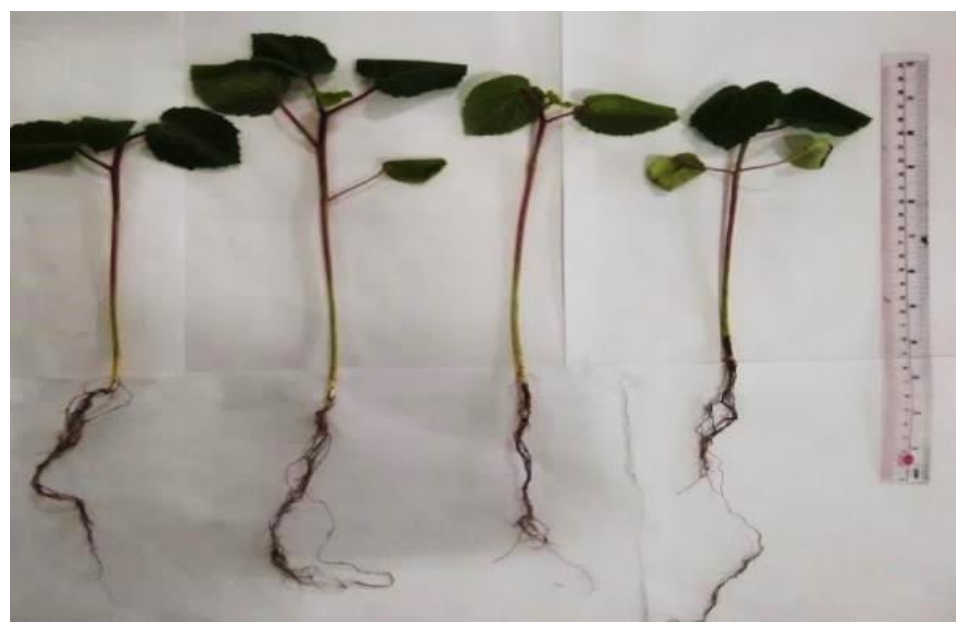

Figure 1. Okra plant height due to MSG treatment at doses of $0,3,6$ and $9 \mathrm{~g}$

The MSG application enhanced the height of the okra plant, but there were no differences between each dosage. The plant fresh and dry weight showed that the highest weight increase at $3 \mathrm{~g}$ MSG, however, the $6 \mathrm{~g}$ and $9 \mathrm{~g}$ dosages showed no differences with the control. Three grams of MSG increased the leaf area, yet the higher dosage showed a decrease in leaf area (Tabel 1).

The increase of okra plant was caused by the sodium and glutamate on the MSG. In plants, sodium $(\mathrm{Na})$ was the micronutrient that could replace the role of potassium $(\mathrm{K})$, which was increasing the turgor cell (Wakeel et al., 2011). The maintenance of plant turgor was very important for photosynthesis and metabolism function well (Zlatev \& Lidon, 2012). Sodium acts as the controller of osmosis pressure in the vacuole and specific function in the cytoplasm which replace $\mathrm{K}^{+}$binds to molybdenum. That caused the nitrate reductase (ANR) activity not disturbed (Wakeel et al., 2011). Accorded to Eisenach \& De Angeli (2017), in some plants sodium had a functional role in stomata physiology which served as osmoticum during the stomatal opening.
Wakeel et al. (2011) asserted that sodium application was stimulated the wheat growth, enhanced antioxidant enzyme activities in Kimchi Cabbage leaves (Lee et al., 2017). Horie et al. (2007) showed that potassium (Na) could increase rice plant growth under the lack of $\mathrm{K}^{+}$.

In plants, glutamate could act as the nitrogen donor that supported growth. Kan et al. (2017) research showed that active conversion between glutamate and $\alpha$ ketoglutaric directly linked to nitrogen and carbon-nitrogen could strengthen the signal path to controlled metabolism response, growth, and defense in rice plant. Nitrogen could increase photosynthesis activity, dividing, and cell multiplication, also increased plant growth and production (Bassi et al., 2018). Accorded to Zhang et al. (2017), nitrogen had the main role to stimulate overall growth, particularly stem growth. Nitrogen from glutamate could increase height growth in the red okra plant (Figure 1). This is aligned with the research by Gresinta (2015), that $3 \mathrm{~g}$ and $6 \mathrm{~g}$ MSG increased the peanut (A. hypogaea L.) plant height. Application of $5 \mathrm{~g}$ and $15 \mathrm{~g}$ 
MSG could increase the bok choy (Brassica chinensis L.) height (Novi, 2016).

Glutamate also served during $\alpha$ aminolevulinic (ALA) forming which was the precursor in synthetic chlorophyll (Suharja, \& Sutarno, 2009; Tsang et al., 2003). The higher the chlorophyll formed, the faster the chlorophyll rate, therefore the plant growth could be faster and maximum. The formed photosynthates (the result of photosynthesis) would be translocated to create new organs, where the larger plant organs are formed, the higher water content that could be bounded by the plant. That process is affected by the plant's fresh weight. Besides, the fresh weight of the plant is affected by the okra plant's fresh weight and leaf area (Figure 1). The end product from photosynthesis was glucose, which was an organic material in a plant cell that formed cytoplasm, cell nucleus, and cell wall, therefore it affected the accumulation of plant organic compound. According to Ou et al. (2017), the accumulation of plant organic compound was the result of plant synthetic from inorganic compounds such as water and carbon dioxide. Therefore, it gave a contribution to the dry weight of the plant.

Monosodium glutamate application in $6 \mathrm{~g}$ and $9 \mathrm{~g}$ dosages on fresh weight and dry weight of plant did not show the real difference with the control (Table 1). These matters showed that the optimal dosage on MSG for the red okra plant was $3 \mathrm{~g}$ per plant. The research conducted by Novi (2016) showed that MSG application with more than $15 \mathrm{~g}$ per plant would make the peanut (A. hypogea L.) became stunt, caused withered leaf, and showed yellowing. Those proved that the optimum dosage for each plant was different. According to (Liu et al., 2014), excessive application of fertilizer would increase the level of an excess nutrient, thus the absorption of other elements on the soil would be disrupted and obstructed plant growth.

Monosodium glutamate application did not affect the red okra leaves number. It believed that the MSG composition was more focused on the height of the plant and the leaf area of the okra plant rather than leaf formation. Observation on plant growth could also be seen from the leaf morphology of okra plant leaves. Monosodium glutamate treatment in $3 \mathrm{~g}, 6 \mathrm{~g}$, and $9 \mathrm{~g}$ dosages showed a larger leaf area (Figure 1). Accorded to (Li et al., 2013), nitrogen could cause plant leaf to be larger and broaden the space for the photosynthesis process.

Generative Growth of Red Okra Plant. Productivity of Red Okra Plant. The Analysis of Variance test showed that MSG application affected the flowering time, flowers number, fruit number, and percentage of flower that became fruit in red okra (Table 2).

Table 2. Flowering time, flowers number, fruit number, percentage of flower becoming fruit in okra plant that applied with MSG.

\begin{tabular}{|c|c|c|c|c|}
\hline \multirow{2}{*}{ Variable } & \multicolumn{4}{|c|}{ MSG Dosage (g) } \\
\hline & 0 & 3 & 6 & 9 \\
\hline Flowering time (day) & $34.8^{\mathrm{a}}$ & $30.8^{\mathrm{b}}$ & $32.8^{\mathrm{ab}}$ & $32.4^{\mathrm{ab}}$ \\
\hline Number of Flowers & $6^{\mathrm{b}}$ & $8^{a}$ & $8.2^{\mathrm{a}}$ & $8.4^{\mathrm{a}}$ \\
\hline Number of Fruit & $1.6^{\mathrm{b}}$ & $2.8^{\mathrm{a}}$ & $2.8^{\mathrm{a}}$ & $2.6^{\mathrm{a}}$ \\
\hline $\begin{array}{l}\text { Percentage of } \quad \text { Flower } \\
\text { becoming Fruit }(\%)\end{array}$ & $27.38^{\mathrm{b}}$ & $35.5^{\mathrm{a}}$ & $36.67^{\mathrm{a}}$ & $30.83^{\mathrm{ab}}$ \\
\hline
\end{tabular}

Duncan's Multiple Range Test showed that MSG application in 4 different dosages could fasten the flowering time, however in $6 \mathrm{~g}$ and 9 $\mathrm{g}$ dosages showed a similar result compared to the control. Monosodium glutamate application increased the okra flower number and the fruit number. The $3 \mathrm{~g}$ and $6 \mathrm{~g}$ dosages of MSG increased the percentage of flower that became fruit, while with $9 \mathrm{~g}$ of MSG decreased the percentage of flower becoming fruit (Table 2).

The increased production of okra was caused by the glutamate that acted as the nitrogen donor. Increased nitrogen in the okra plant would affect photosynthesis, which could increase the okra growth in the vegetative phase and plants would store more carbohydrates as fuel for flower formation. Cho et al. (2018) 
stated that flower induction is influenced by high glucose content on the shoot, as the base energy source for flower induction process and also the growth process of meristem and flower parts.

Glutamate played the role in the forming of 2-oxoglutarate (2-OG). The 2-oxoglutarate was the main organic acid from the TCA cycle, it was also a required substrate for 2-OGdependent dioxygenases. The oxidative reaction that was catalyzed by 2-ODDs was taken part in the phytohormone biosynthetic process, such as gibberellin (Araujo et al., 2014). Accorded to Gupta \& Chakrabarty (2013), gibberellin stimulated flowering initiation by increasing mitosis in apical meristem to be responsive to the flowering stimulant. Gresinta (2015) stated that giving MSG in $3 \mathrm{~g}$ and $6 \mathrm{~g}$ dosages could fasten the flowering time in the peanut plant. Dewantri et al. (2017), also stated that MSG could fasten blooming in Rombusa mini plant (Tabernaemontana corymbosa).

Gibberellin also stimulated synthetic hydrolytic enzymes such as amylase and protease that were able to digest starch and protein, this process increased the glucose content and amino acid for cell growth. An Amino acid that was formed due to the activity of the protease enzyme was the precursor of how tryptophan formed, which was the precursor of auxin (Zhao, 2014). The increased auxin would prevent the abscission sensitivity zone to ethylene, therefore could delay the process of dying flower and increased the quality of fruit (Iqbal et al., 2017). Okra flowers that were not easily released would increase the percentage of flowers becoming fruit.

Accorded to Iqbal et al. (2017), the success of the reproduction process of one plant depended on its ability to exceed the growth step that began from flower bud initiation until the fruit and pit became ripe. The ability of the okra plant to exceed the growth phase was because of the glutamate that acted as the plant's defense mechanism (Kan et al., 2017). Seifi et al. (2013) stated that glutamate was served in amino acid biosynthesis just like $\gamma$ aminobutyric acid (GABA), arginine, and proline served as plants defense. Glutamate was also needed from synthetic glutathione, where plants used glutathione to xenobiotic detoxification, herbicide, air pollutants (sulfur dioxide and ozone) and also toxic heavy metal (Galant et al., 2011).

The Growth of Red Okra Plant. Analysis of Variance results with the level of assumption at $95 \%$ showed that MSG treatment had a real effect on the weight, length, and diameter of okra fruit (Table 3).



Figure 2. Six days after pollination Red okra fruit that applied with MSG

The DMRT test result showed that MSG application increased the weight of okra fruit. Monosodium glutamate with $3 \mathrm{~g}$ dosage increased the fruit length, however in $6 \mathrm{~g}$ and 9 $\mathrm{g}$ dosage resulted in similar results compared to the control. The $3 \mathrm{~g}$ MSG increased the diameter of okra fruit, however in higher dosage decreased the fruit diameter (Table 3 ).

The increased growth of red okra fruit was caused by glutamate that stimulated the gibberellin hormone. Accorded to Batlang (2008), the application of gibberellin could 
induce the cell so that it enhanced the fruit size. Gibberellin increased metabolism photosynthesis rate, therefore the formed carbohydrate could be used for fruit formation. This caused okra plant that is treated by MSG would have longer fruit (Figure 2).

\section{CONCLUSION}

Monosodium Glutamate application enhances the growth of red okra, including plant height, fresh weight, dry weight, and leaf area. However, it does not affect the growth of the leaf number. Monosodium Glutamate application also enhances the productivity of red okra, which includes; flowering time, flower number, fruit number, percentage of flower becoming fruit, the fruit weight, length, and diameter. The $3 \mathrm{~g}$ dosage of MSG per plant is the optimum dosage for red okra growth and production. The results of this study can be used as a reference to increase okra production with simple techniques and low-cost.

\section{ACKNOWLEDGMENTS}

Authors would like to thank the Laboratory of Plant Biology Structure and Function, Department of Biology, Faculty of the Science and Mathematics, Universitas Diponegoro that facilitated this research.

\section{REFERENCES}

Almeida DM, Oliveira MM, Saibo NJ. 2017. Regulation of $\mathrm{Na}+$ and $\mathrm{K}+$ homeostasis in plants: towards improved salt stress tolerance in crop plants. Genetics and molecular biology. vol 40(1): 326-345. doi: http://dx.doi.org/10.1590/1678-4685gmb-2016-0106.

Araújo WL, Martins AO, Fernie AR, Tohge T. 2014. 2-Oxoglutarate: linking TCA cycle function with amino acid, glucosinolate, flavonoid, alkaloid, and gibberellin biosynthesis. Frontiers in plant science. vol 5: 1-6. doi: https://doi.org/10.3389/fpls.2014.00552.

Batlang U. 2008. Benzyladenine plus gibberellins $(\mathrm{GA} 4+7)$ increase fruit size and yield in greenhouse-grown hot pepper (Capsicum annuum L.). Journal of Biological Sciences. vol 8(3): 659-662. doi:

http://dx.doi.org/10.3923/jbs.2008.659.66 2.

Bassi D, Menossi M, Mattiello L. 2018. Nitrogen supply influences photosynthesis establishment along the sugarcane leaf. Scientific reports. vol 8(1): 1-13. doi: https://doi.org/10.1038/s41598-01820653-1.

Cho LH, Pasriga R, Yoon J, Jeon JS, An G. 2018. Roles of sugars in controlling flowering time. Journal of Plant Biology. vol 61(3): 121-130. doi: https://doi.org/10.1007/s12374-018-0081$\mathrm{z}$.

Dewantri MY, Wicaksono KP, Sitawati S. 2018. Respon Pemberian Pupuk NPK dan Monosodium Glutamat (MSG) Terhadap Pembungaan Tanaman Rombusa Mini (Tabernaemontana corymbosa). Jurnal Produksi Tanaman. vol 5(8): 1301-1307.

Eisenach C, and De Angeli A. 2017. Ion transport at the vacuole during stomatal movements. Plant physiology. vol 174(2): 520-530.

doi: https://doi.org/10.1104/pp.17.00130.

Galant A, Preuss ML, Cameron J, Jez JM. 2011. Plant glutathione biosynthesis: diversity in biochemical regulation and reaction products. Frontiers in plant science. vol. 2: $1-7$. doi: https://doi.org/10.3389/fpls.2011.00045.

Gresinta E. 2015. Pengaruh pemberian monosodium glutamat (MSG) terhadap pertumbuhan dan produksi kacang tanah (Arachis hypogea L.). Faktor Exacta. vol 8(3): 208-219. doi: http://dx.doi.org/10.30998/faktorexacta.v8 i3.322.

Gupta R, and Chakrabarty SK. 2013. Gibberellic acid in plant: still a mystery unresolved. Plant signaling \& behavior. vol 8(9): e255041-e255042. doi: https://doi.org/10.4161/psb.25504.

Habiba RN, Slamet W, Fuskhah E. 2018. Pertumbuhan dan produksi Okra merah (Abelmoschus esculentus L. Moench) pada dosis pupuk kompos serasah yang berbeda dan pemangkasan. Journal of Agro 
Complex. vol 2(2): 180-187. doi: https://doi.org/10.14710/joac.2.2.180-187.

Horie T, Costa A, Kim TH, Han MJ, Horie R, Leung HY, Miyao A, Hirochika H, An G, Schroeder JI. 2007. Rice OsHKT2; 1 transporter mediates large $\mathrm{Na}+$ influx component into $\mathrm{K}+$-starved roots for growth. The EMBO journal. vol 26(12): 3003-3014. doi: https://doi.org/10.1038/sj.emboj.7601732.

Iqbal N, Khan NA, Ferrante A, Trivellini A, Francini A, Khan MIR. 2017. Ethylene role in plant growth, development and senescence: interaction with other phytohormones. Frontiers in plant science. vol 8: 475 . doi: https://doi.org/10.3389/fpls.2017.00475.

Kan CC, Chung TY, Wu HY, Juo YA, Hsieh MH. 2017. Exogenous glutamate rapidly induces the expression of genes involved in metabolism and defense responses in rice roots. BMC genomics. vol 18(1): 186. doi: https://doi.org/10.1186/s12864-017-35887.

Lee HJ, Kim JS, Lee SG, Kim SK, Mun B, Choi CS. 2017. Glutamic acid foliar application enhances antioxidant enzyme activities in kimchi cabbages leaves treated with low air temperature. Horticultural Science and Technology. vol 35(6): 700-706. doi: https://doi:org/10.12972/kjhst.20170074.

Li Y, Ren B, Ding L, Shen Q, Peng S, Guo S. 2013. Does chloroplast size influence photosynthetic nitrogen use efficiency? PloS one. vol 8(4): e62036. doi: https://dx.doi.org/10.1371\%2Fjournal.pon e.0062036.

Liu CW, Sung Y, Chen BC, Lai HY. 2014. Effects of nitrogen fertilizers on the growth and nitrate content of lettuce (Lactuca sativa L.). International journal of environmental research and public health. vol 11(4): 4427-4440. doi: https://doi.org/10.3390/ijerph110404427.

Löliger J. 2000. Function and importance of glutamate for savory foods. The Journal of nutrition. vol 130(4): 915S-920S. doi: https://doi.org/10.1093/jn/130.4.915S.

Novi N. 2016. Pemanfaatan monosodium glutamat dalam meningkatkan pertumbuhan vegetatif tanaman pakcoy (Brassica chinensis L). Jurnal BioConcetta. vol 2(1): 69-74. doi: https://doi.org/10.22202/bc.2016.v2i1.148 6.

Ou X, Yang Y, Guo L, Zhu D, Liu D. 2017. Effect of organic-inorganic $\mathrm{N}$ sources on growth, NPK nutrients and secondary metabolites of Panax Notoginseng (Burk.) FH Chen. Emirates Journal of Food and Agriculture. vol 29(8): 629-638. doi: https://doi.org/10.9755/ejfa.2016-10-1528.

Seifi HS, Van Bockhaven J, Angenon G, Höfte M. 2013. Glutamate metabolism in plant disease and defense: friend or foe? Molecular Plant-Microbe Interactions. vol 26(5): 475-485. doi: https://doi.org/10.1094/MPMI-07-120176-CR.

Suharja, and Sutarno. 2009. Biomass, chlorophyll and nitrogen content of leaves of two chili pepper varieties (Capsicum annum) in different fertilization treatments. Nusantara Bioscience. vol 1(1): 9-16. doi: https://doi.org/10.13057/nusbiosci/n01010 2.

Tsang EW, Yang J, Chang Q, Nowak G, Kolenovsky A, McGregor DI, Keller WA. 2003. Chlorophyll reduction in the seed of Brassica napus with a glutamate 1semialdehyde aminotransferase antisense gene. Plant molecular biology. vol 51(2): 191-201.

doi: https://doi.org/10.1023/A:1021102118801

Wakeel A, Farooq M, Qadir M, Schubert S. 2011. Potassium substitution by sodium in plants. Critical reviews in plant sciences. vol 30(4): 401-413. doi: https://doi.org/10.1080/07352689.2011.58 7728.

Zhang L, Yang X, Gao D, Wang L, Li J, Wei Z, Shi Y. 2017. Effects of poly- $\gamma$-glutamic acid $(\gamma$-PGA) on plant growth and its distribution in a controlled plant-soil system. Scientific reports. vol 7(1): 1-13. doi: https://doi.org/10.1038/s41598-01706248-2.

Zhao Y. 2014. Auxin biosynthesis. The Arabidopsis Book/American Society of 
Plant Biologists. vol 12: e0173. doi: https://dx.doi.org/10.1199\%2Ftab.0173.

Zlatev Z, and Lidon FC. 2012. An overview on drought induced changes in plant growth, water relationsand photosynthesis. Emirates Journal of Food and Agriculture. vol 24(1): 57-72. doi: https://doi.org/10.9755/ejfa.v24i1.10599. 